九州大学学術情報リポジトリ

Kyushu University Institutional Repository

\title{
An Analysis on Income Status of Farm Households : A Case Study in the Red River Delta of Vietnam
}

Dung, Nguyen Mau

Laboratory of Farm management, Division of International Agricultural Resource Economics and Business Administration, Department of Agricultural and Resource Economics, Graduate School of Bioresources and Bioenvironmental Sciences, Kyushu University

Tsuji, Masao

Laboratory of Farm management, Department of Agricultural and Resource Economics, Graduate School of Bioresources and Bioenvironmental Sciences, Kyushu University

https://doi.org/10.5109/24385

出版情報：九州大学大学院農学研究院紀要. 45 (1)，pp.365-380，2000-11. Kyushu University バージョン：

権利関係 : 


\title{
An Analysis on Income Status of Farm Households - A Case Study in the Red River Delta of Vietnam -
}

\author{
Nguyen Mau Dung* and Tsuji Masao \\ Laboratory of Farm Management, Department of Agricultural and Resource Economics, \\ Graduate school of Bioresource and Bioenvironment Sciences, \\ Kyushu University 46-01, Fukuoka 812-8581, Japan \\ (Received July 31, 2000 and accepted August 18, 2000)
}

\begin{abstract}
Since 1988 with the effect of agricultural policy reform, farm household in Vietnam has been considered as an autonomous economic unit. Despite the equal land distribution in the Red River delta, the differences in socioeconomic conditions and farming skills of farm households resulted in the different efficiency of resource use and farm household income. This study was carried out to analyze characteristics and income status of farm households in the Red River delta of Vietnam. A questionnaire survey on characteristics of farm households and results of production activities was conducted to collect necessary data. Results of the study indicated that there were differences in income structures, in scopes and outcomes of farming and non-farming activities according to locations and farm household groups due to the various socioeconomic conditions in farm households. The diversification of farm household economy through the simultaneous development of farming and non-farming activities was the appropriate way to alleviate poverty and improve the life quality of farmers in the delta.
\end{abstract}

\section{INTRODUCTION}

Vietnam is an agricultural country with over 80 percent of its population and around 70 percent of labor forces now living in rural areas. Development of Vietnam is only meaningful if the rural masses can achieve higher incomes and a better life. Being one of two largest rice bowls of Vietnam, the Red River Delta provides a considerable rice output and other agricultural products for domestic consumption and for export. With the effects of the policy reform (DOIMOI) in agricultural sector since 1988, farm households in the delta have been considered as autonomous economic units, which can make owned decisions on production plans based on their resources available. Despite the equal land distribution, the differences in socioeconomic conditions and farming skills of farm households result in the different efficiency of resource use and farm household income. While a number of farm households in the region have become the rich after the reform policy, many farmers still remain the poor. Although the farm household classification by income levels has been existed in the country, the socioeconomic conditions as well as income structures of farm household categories are not well examined, yet. Therefore a question arises as to why there are the differences in income attainment among farm households. To seek the answer to the above question, this study focuses on analyzing the characteristics of farm households and examining how different income was made

\footnotetext{
* Laboratory of Farm Management, Division of International Agricultural Resource Economics and Business Administration, Department of Agricultural and Resource Economics, Graduate school of Bioresouce and Bioenvironment Sciences, Kyushu University, 46-01, Fukuoka 812-8581, Japan.
} 
from crop production, livestock breeding and non-farming activities among farm households in the delta.

\section{METHODOLOGY}

\section{Selected survey areas and sampled farm households}

Red River Delta is situated in the north of Vietnam covering a total area of $1,250,000$ hectares of 8 provinces. For collecting necessary data, three communes namely Daidong, Ninhhiep and Taygiang, located in three ecological zones in the Red River Delta were selected for survey (figure 1). Of which, Daidong and Taygiang communes situated in the up-stream zone and coastal zone respectively, far from Hanoi capital, concentrate on farming activities; Ninhhiep commune located in central zone and very near to Hanoi capital, concentrates on non-farming activities as showed in table 1. Because of equal land reallocation in the Delta, the landholding does not appear to be an appropriate indicator to classify farm households as it is commonly used in developing countries. To classify the farm household through out the delta, farm household income status was

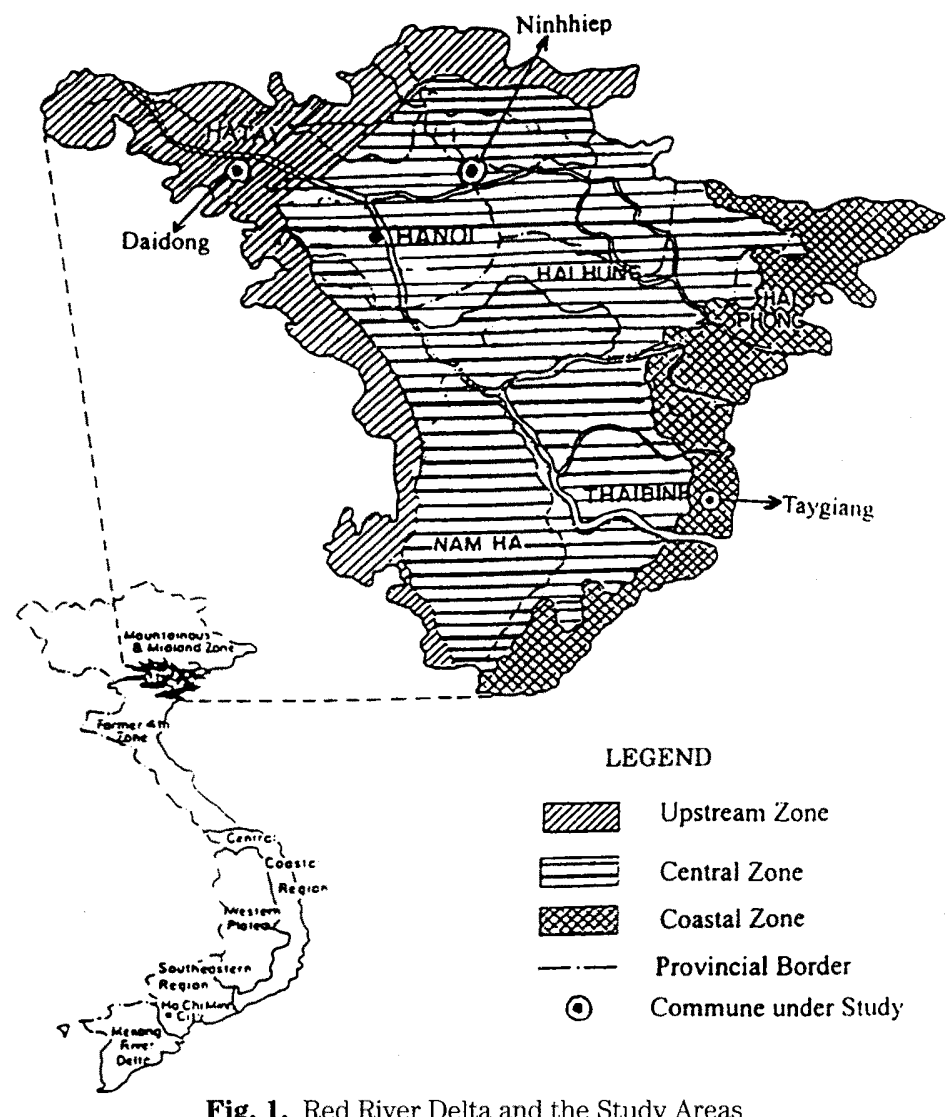

Fig. 1. Red River Delta and the Study Areas 
taken into consideration.

Based on income level for calorie intake criterion and making allowance for non-food basic needs, including education, health care, travel and cultural expenses, farm households in the study areas are classified into 3 categories as follows:

- Low-income household: per-capita income per month is lower than 70 thousand VND. This is the minimum amount required to allow the consumption of minimum basket of goods.

- Medium-income household: per-capita income per month ranges from 70 to 175 thousand VND. This is enough for daily life requirement at average level; small saving is possible.

- High-income household: per-capita income per month is greater than 175 thousand VND. This is abundant amount for the daily life requirement and significant saving.

Table1. General information of the commune under study

\begin{tabular}{lcccc}
\hline \multicolumn{1}{c}{ Item } & Unit & \multicolumn{3}{c}{ Commune } \\
\cline { 3 - 5 } & & Ninhhiep & Daidong & Taygiang \\
\hline 1. Total farm population & person & 11885 & 7813 & 5265 \\
2. Labor force & " & 4783 & 3841 & 2033 \\
3. Total household & household & 2455 & 1973 & 1575 \\
4. Total farm household & " & 2288 & 1917 & 1383 \\
$\quad$ - High income & $\%$ & 34.02 & 19.51 & 26.83 \\
- Medium income & $\%$ & 54.46 & 52.73 & 51.48 \\
- Low income & $\%$ & 11.52 & 27.76 & 21.69 \\
5. Agricultural land & ha & 338.3 & 390.3 & 334.2 \\
6. Total sown area & " & 697.6 & 984.4 & 666.6 \\
7. Rice sown area & " & 624.4 & 760.4 & 593.0 \\
$\quad$ - Rice yield per crop & ton/ha & 4.53 & 5.01 & 5.68 \\
8. Proportion of Total Product Value & & & & \\
$\quad$ - Crop & $\%$ & 14.32 & 45.44 & 44.87 \\
- Livestock & $\%$ & 7.14 & 19.93 & 25.21 \\
- Non-farming activities & $\%$ & 75.54 & 35.23 & 30.92 \\
\hline
\end{tabular}

Source: From field survey, February 2000

Based on the proportion of high, medium and low-income households in the communes, a total of 60 farm households were selected for survey. Number of sampled households in each commune and category was illustrated in table 2.

Farm household economy in the delta consists of farming and non-farming activities. Farming activities are characterized by the integration of crop and livestock, which has been practiced since long. Non-farming activities, which create employment and contribute to alleviation of the labor pressure on the limited land, at present play a notable part to total earning of the farm households. Therefore the performance of crop production, livestock breeding, and non-farming activities in the households are taken into considerations.

\section{Data collection and analysis method}

Data was collected from sampled farm households through out a survey of 3 
communes using a standard questionnaire for year 1999, which had normal weather condition. The descriptive statistic tools were used to analyze the collected data.

\section{Farm household income}

In the Red River Delta, due to labor surplus in farm households, high income attainment from the production activities is the ultimate objective of the farm households. Income indicator is widely used by researchers to analyze the performance of a particular farm enterprise. The income of an enterprise is defined as the enterprise gross return minus the production cost (excluding the family labor cost) attributable to that enterprise:

Income $=$ Gross Return - Production Cost

Where gross return includes total product value and value of by-products. Production cost covers material cost, hired labor cost, land tax, and interest on loans. For people working as hired laborer, their income is the earning they received from their work.

\section{SOCIOECONOMIC CHARACTERISTICS OF FARM HOUSEHOLDS}

The socioeconomic status of farm households is an important component of farming system, for which, it is one of the determinants of level and efficiency of resource use. This part attempts to provide an insight into socioeconomic of farm households in the region.

\section{Socio-demographic characters of farm households}

The householders' age ranged from 35 to 65 with an average of 48.53 year indicating that they have much farming experience. Although all farm householders were literate,

Table 2. Socio-demographic characters of farm households

\begin{tabular}{|c|c|c|c|c|c|c|c|c|}
\hline \multirow{2}{*}{$\begin{array}{l}\text { Com- } \\
\text { mune }\end{array}$} & \multirow{2}{*}{$\begin{array}{l}\text { Farm } \\
\text { Group }\end{array}$} & \multirow{2}{*}{$\begin{array}{c}\text { No. of } \\
\text { sampled } \\
\text { households }\end{array}$} & \multirow{2}{*}{$\begin{array}{c}\text { Age of } \\
\text { householder } \\
\text { (year) }\end{array}$} & \multirow{2}{*}{$\begin{array}{l}\text { Education } \\
\text { (year) }\end{array}$} & \multirow{2}{*}{$\begin{array}{l}\text { Family size } \\
\text { (person) }\end{array}$} & \multirow{2}{*}{$\begin{array}{c}\text { Active } \\
\text { labor } \\
\text { (person) }\end{array}$} & \multicolumn{2}{|c|}{ Occupation } \\
\hline & & & & & & & $\begin{array}{l}\text { Farming } \\
\text { only (\%) }\end{array}$ & $\begin{array}{l}\text { Farming and } \\
\text { non-farming }(\%)\end{array}$ \\
\hline \multirow{4}{*}{$\begin{array}{l}\text { Ninh } \\
\text { hiep }\end{array}$} & High & 7 & 50.5 & 6.7 & 5.1 & 2.8 & 0.0 & 100.0 \\
\hline & Medium & 8 & 48.6 & 5.9 & 5.0 & 2.8 & 25.0 & 75.0 \\
\hline & Low & 5 & 53.2 & 4.9 & 5.7 & 2.9 & 60.0 & 40.0 \\
\hline & Total & 20 & 50.4 & 5.9 & 5.2 & 2.8 & 25.0 & 75.0 \\
\hline \multirow{4}{*}{$\begin{array}{c}\text { Dai } \\
\text { dong }\end{array}$} & High & 5 & 47.5 & 7.1 & 4.8 & 2.6 & 40.0 & 60.0 \\
\hline & Medium & 8 & 50.6 & 6.4 & 4.8 & 2.5 & 62.5 & 37.5 \\
\hline & Low & 7 & 46.4 & 5.1 & 5.1 & 2.7 & 71.4 & 28.6 \\
\hline & Total & 20 & 48.4 & 6.1 & 4.9 & 2.6 & 60.0 & 40.0 \\
\hline \multirow{4}{*}{$\begin{array}{l}\text { Tay } \\
\text { giang }\end{array}$} & High & 6 & 48.0 & 6.9 & 4.8 & 2.6 & 50.0 & 50.0 \\
\hline & Medium & 8 & 48.2 & 6.1 & 4.7 & 2.7 & 62.5 & 37.5 \\
\hline & Low & 6 & 44.5 & 5.3 & 4.9 & 2.5 & 66.7 & 33.3 \\
\hline & Total & 20 & 47.0 & 6.1 & 4.8 & 2.6 & 66.7 & 33.3 \\
\hline
\end{tabular}

Source: From field survey, February 2000 
householders in high-income group had higher educational attainment as compared with householders in other groups.

Family size and labor were not much different among groups. However, dependent burden in low-income group was higher than that in other ones. In respect to occupation, most farm households in Ninhhiep commune engaged in non-farming activities while farmers in Daidong and Taygiang engaged non-farming at lower rates. High and medium-income households engaged non-farming at higher rates. The remains of sole farming households mainly appeared in the low-income groups as in table 2 .

\section{Cropland and assets for crop production in farm households}

After the reform in 1988 and new land law in 1993, cropland had been reallocated to farm households under the equality principle. Cropland was therefore scattered and dispersed (Chung, 1994). The average of assignment areas was very small as around 0.2 hectare per household and various among locations. Due to available credit, high income households tended to rent in more land for crop cultivation while medium and low-income ones rented the smaller areas with the exception of Ninhhiep commune where farming was not paid much attention by high income households. High-income households also equipped more assets for productive activities. The value of main assets and cash for production in high-income group were higher than those of medium and low-income ones as illustrated in table 3 .

\section{Income, expenditure and saving in farm household.}

Income structures in the farm household were different among locations. In Ninhiep, main income came out from the non-farming while in Daidong and Taygiang, income from crop and livestock accounted for the essential parts. The low-income ones earned

Table 3. Crop land and main assets for production activities in farm households

\begin{tabular}{|c|c|c|c|c|c|c|c|c|c|}
\hline \multirow{2}{*}{$\begin{array}{l}\text { Com- } \\
\text { mune }\end{array}$} & \multirow{2}{*}{$\begin{array}{l}\text { Farm } \\
\text { Group }\end{array}$} & \multicolumn{2}{|c|}{ Crop land } & \multicolumn{5}{|c|}{ Main assets } & \multirow{2}{*}{$\begin{array}{l}\text { Cash used for } \\
\text { production } \\
\text { activities } \\
\text { (1000d) }\end{array}$} \\
\hline & & $\begin{array}{l}\text { Assign- } \\
\text { ment } \\
\left(\mathrm{m}^{2}\right)\end{array}$ & $\begin{array}{l}\text { Rented } \\
\text { in } \\
\left(\mathrm{m}^{2}\right)\end{array}$ & $\begin{array}{l}\text { Thresher } \\
\text { In number }\end{array}$ & $\begin{array}{l}\text { Pesticide } \\
\text { sprayer } \\
\text { In number }\end{array}$ & $\begin{array}{l}\text { Transport } \\
\text { equipment } \\
\text { In number }\end{array}$ & $\begin{array}{c}\text { Buffalo } \\
\text { and cattle } \\
\text { In number }\end{array}$ & $\begin{array}{c}\text { Total } \\
\text { Value } \\
(1000 d)\end{array}$ & \\
\hline \multirow{4}{*}{$\begin{array}{l}\text { Ninh } \\
\text { hiep }\end{array}$} & High & 1550.0 & 0.0 & 0.1 & 0.7 & 0.6 & 0.0 & 1690.0 & 4181.4 \\
\hline & Medium & 1360.0 & 516.0 & 0.1 & 0.6 & 0.6 & 0.1 & 1205.0 & 2130.0 \\
\hline & Low & 1348.0 & 290.0 & 0.1 & 0.6 & 0.7 & 0.0 & 560.0 & 410.0 \\
\hline & Average & 1423.5 & 278.9 & 0.1 & 0.6 & 0.6 & 0.1 & 1213.5 & 2418.0 \\
\hline \multirow{4}{*}{$\begin{array}{c}\text { Dai } \\
\text { dong }\end{array}$} & High & 1852.0 & 462.0 & 0.7 & 1.0 & 1.0 & 0.2 & 2120.0 & 2150.0 \\
\hline & Medium & 2092.0 & 278.0 & 0.3 & 0.8 & 0.9 & 0.3 & 1025.0 & 1320.0 \\
\hline & Low & 2245.0 & 177.0 & 0.2 & 0.7 & 0.7 & 0.0 & 480.0 & 350.0 \\
\hline & Average & 2085.6 & 288.7 & 0.3 & 0.8 & 0.8 & 0.2 & 1108.0 & 1188.0 \\
\hline \multirow{4}{*}{$\begin{array}{l}\text { Tay } \\
\text { giang }\end{array}$} & High & 2179.0 & 1098.0 & 0.5 & 1.0 & 1.0 & 0.2 & 2109.0 & 2270.0 \\
\hline & Medium & 2190.0 & 672.0 & 0.3 & 0.9 & 0.9 & 0.3 & 1090.0 & 1500.0 \\
\hline & Low & 2376.0 & 238.0 & 0.2 & 0.6 & 0.8 & 0.0 & 524.0 & 360.0 \\
\hline & Average & 2242.5 & 669.6 & 0.3 & 0.8 & 0.9 & 0.2 & 1225.9 & 1389.0 \\
\hline
\end{tabular}

Source: From field survey, February 2000 
Table 4. Total income, expenditure and saving in farm household (unit: 1000 VND)

\begin{tabular}{|c|c|c|c|c|c|c|c|c|}
\hline \multirow{2}{*}{$\begin{array}{l}\text { Com- } \\
\text { mune }\end{array}$} & \multirow{2}{*}{$\begin{array}{l}\text { Farm } \\
\text { group }\end{array}$} & \multicolumn{4}{|c|}{ Income } & \multicolumn{2}{|c|}{ Expenditure } & \multirow[b]{2}{*}{ Saving } \\
\hline & & Total & $\begin{array}{c}\text { Crop } \\
\text { production }\end{array}$ & $\begin{array}{l}\text { Livestock } \\
\text { breeding }\end{array}$ & Non-farming & Total & $\begin{array}{l}\text { Food and } \\
\text { drink }\end{array}$ & \\
\hline \multirow{4}{*}{$\begin{array}{l}\text { Ninh } \\
\text { hiep }\end{array}$} & High & 13328.4 & 1456.9 & 568.6 & 11302.9 & 9863.0 & 5230.5 & 3465.4 \\
\hline & Medium & 9247.6 & 2045.2 & 999.3 & 6203.1 & 7398.1 & 4358.7 & 1849.5 \\
\hline & Low & 5283.7 & 1895.6 & 703.4 & 2684.7 & 4913.9 & 3646.7 & 369.9 \\
\hline & Average & 9684.9 & 1801.9 & 774.6 & 7108.4 & 7639.7 & 4485.8 & 2045.2 \\
\hline \multirow{4}{*}{$\begin{array}{c}\text { Daí } \\
\text { dong }\end{array}$} & High & 11068.0 & 3514.7 & 3263.5 & 4289.8 & 8854.4 & 4790.5 & 2213.6 \\
\hline & Medium & 7794.8 & 3172.4 & 1761.3 & 2861.1 & 6625.6 & 3914.7 & 1169.2 \\
\hline & Low & 4744.9 & 2814.4 & 582.2 & 1348.3 & 4792.4 & 3241.5 & -47.4 \\
\hline & Average & 7545.6 & 3132.7 & 1724.2 & 2688.8 & 6507.9 & 3898.1 & 1037.7 \\
\hline \multirow{4}{*}{$\begin{array}{l}\text { Tay } \\
\text { giang }\end{array}$} & High & 11879.5 & 4391.9 & 3524.7 & 3962.9 & 9266.0 & 4741.7 & 2613.5 \\
\hline & Medium & 7722.7 & 3451.9 & 1871.4 & 2399.4 & 6487.0 & 3874.4 & 1235.6 \\
\hline & Low & 4719.4 & 2807.0 & 638.2 & 1274.2 & 4625.0 & 3174.0 & 94.4 \\
\hline & Average & 8068.8 & 3540.4 & 1997.4 & 2530.9 & 6762.1 & 3924.4 & 1306.6 \\
\hline
\end{tabular}

Source: From field survey, February 2000

around 5 million VND, the medium ones received approximately 8 million VND while the high-income group got 12 million VND, 1.5 and 2.3 times higher as compared to the medium and low-income one, respectively.

With the small amount of income, the low-income households expensed most their income for daily life requirements such as food, clothes and social expenditures. Therefore they did almost not have savings as illustrated in table 4. This was the reason that constrained their production activities, and drove them into the vicious circle of poverty. The medium and high-income ones had a significant saving and could invest more for reproduction or enlarge their scope of production activities. It resulted in their bigger return in the next production process, especially for high-income ones.

\section{PRODUCTION ACTIVITIES AND INCOME STATUS OF FARM HOUSEHOLDS}

\section{Crop production}

Crop system and cropping intensity in farm households

In the Delta, rice is a dominant crop in the cropping system in all locations. The rice-base farming system also consists of other crops such as maize, potato, vegetable, etc. The diversified climatic condition and farm resource endowments enable farmers in all locations to grow 2 rice crops per year, namely, the spring and summer crops. After harvesting 2 rice crops, lands are available for farmers to grow winter crops of transplanted maize, soybean, sweet potato, vegetable etc. In all farm groups, cropping intensity was higher than two times but much differed from locations. The cropping intensity in Daidong was 2.6 time per year. However, in Ninhhiep, due to easily accessing non-farming activities and their higher comparative advantages in comparison with that of winter crop cultivation, almost farmers there planted winter crop at very small areas, and the cropping intensity there was only 2.06 time. 
Table 5. Input application for rice production by farm income groups (per sao*)

\begin{tabular}{|c|c|c|c|c|c|c|c|}
\hline $\begin{array}{l}\text { Com- } \\
\text { mune }\end{array}$ & $\begin{array}{l}\text { Farm } \\
\text { Group }\end{array}$ & $\begin{array}{c}\text { Manure } \\
\text { (kg) }\end{array}$ & $\begin{array}{l}\text { Urea } \\
(\mathrm{kg})\end{array}$ & $\begin{array}{c}\text { Phosphate } \\
\text { (kg) }\end{array}$ & $\begin{array}{l}\text { Potassium } \\
\qquad(\mathrm{kg})\end{array}$ & $\begin{array}{c}\text { Agro- } \\
\text { chemicals } \\
(1000 \mathrm{VND})\end{array}$ & $\begin{array}{c}\text { Labor } \\
\text { (man-day) }\end{array}$ \\
\hline \multirow{4}{*}{$\begin{array}{l}\text { Ninh } \\
\text { hiep }\end{array}$} & High & 265.2 & 8.1 & 10.8 & 3.2 & 7.5 & 8.1 \\
\hline & Medium & 290.4 & 8.5 & 10.5 & 2.9 & 7.8 & 8.8 \\
\hline & Low & 270.1 & 8.1 & 8.5 & 2.8 & 10.5 & 8.5 \\
\hline & Average & 276.5 & 8.3 & 10.1 & 3.0 & 8.4 & 8.4 \\
\hline \multirow{4}{*}{$\begin{array}{c}\text { Dai } \\
\text { dong }\end{array}$} & High & 409.2 & 8.1 & 13.5 & 4.5 & 6.7 & 9.2 \\
\hline & Medium & 350.6 & 7.8 & 10.5 & 3.7 & 7.5 & 9.5 \\
\hline & Low & 275.3 & 6.9 & 8.0 & 2.5 & 9.2 & 9.5 \\
\hline & Average & 338.9 & 7.6 & 10.4 & 3.5 & 7.9 & 9.4 \\
\hline \multirow{4}{*}{$\begin{array}{l}\text { Tay } \\
\text { giang }\end{array}$} & High & 437.6 & 9.8 & 15.1 & 4.1 & 9.2 & 9.4 \\
\hline & Medium & 352.4 & 8.5 & 11.6 & 3.3 & 10.1 & 9.6 \\
\hline & Low & 287.2 & 7.8 & 7.5 & 2.1 & 12.8 & 9.1 \\
\hline & Average & 358.4 & 8.7 . & 11.4 & 3.2 & 10.6 & 9.4 \\
\hline
\end{tabular}

* sao equals to $360 \mathrm{~m}^{2}$

Source: From field survey, February 2000

\section{Cost and return from crop production}

(1) Rice production

Because rice production is a dominant component in the farming system in the delta, it would be plausible to examine the characteristics of rice production system and the income produced from rice.

- Inputs applied for rice production

Modern varieties were widely adopted in the locations under study. The main varieties were CR203, VN10, Bacuu, and Luongquang with potential for high yield and resistance to pests and diseases. The farm household had a trend of growing several varieties in one crop for risk avoidance and reduction of seasonality of farming

Farmyard manure and chemical fertilizer were applied in rice production in almost households. The applied amount of farmyard manure and chemical fertilizers was substantially high and varies according to locations and farmer groups. In Ninhhiep, the small amount of input application, especially of farmyard manure and labor reflected a vague consideration on rice production as well as other crops. Overall, low-income farmers applied less manure and chemical fertilizer than the high ones due to the absence or small scope of livestock rearing and lack of credit. Due to their shortage of knowledge and farming skill, low-income households seemed to apply fertilizers inappropriately. It in turn resulted in more diseases and pests in their field and more agrochemical costs.

- Income from rice production in farm households

The differences in socioeconomic conditions as well as farming practices resulted in different return of rice output among locations and farm groups. In Daidong and Taygiang, high-income group applied inputs at higher level and reached the highest rice productivity and greatest income while the lowest productivity and income appeared in the low-income group. However, in Ninhhiep, the medium-income households received the highest rice productivity and income while the high-income ones obtained the lowest 
Table 6. Income from rice production by farm income groups (per sao)

\begin{tabular}{|c|c|c|c|c|c|c|c|c|c|}
\hline \multirow{3}{*}{$\begin{array}{l}\text { Com- } \\
\text { mune }\end{array}$} & \multirow{3}{*}{$\begin{array}{l}\text { Farm } \\
\text { group }\end{array}$} & \multicolumn{2}{|c|}{ Return } & \multicolumn{5}{|c|}{ Cost } & \multirow{3}{*}{$\begin{array}{l}\text { Income } \\
\text { (1000VND) }\end{array}$} \\
\hline & & \multirow{2}{*}{$\begin{array}{c}\text { Yield } \\
(\mathrm{kg} / \mathrm{sao})\end{array}$} & \multirow{2}{*}{$\begin{array}{c}\text { Gross } \\
\text { return } \\
(1000 \mathrm{VND})\end{array}$} & \multirow{2}{*}{$\begin{array}{l}\text { Material cost } \\
(1000 \mathrm{VND})\end{array}$} & \multicolumn{2}{|c|}{ Labor cost } & \multirow{2}{*}{$\begin{array}{c}\text { Other } \\
\text { (1000VND) }\end{array}$} & \multirow{2}{*}{$\begin{array}{c}\text { Total } \\
(1000 \mathrm{VND})\end{array}$} & \\
\hline & & & & & $\begin{array}{l}\text { Total cost } \\
(1000 \mathrm{VND})\end{array}$ & $\begin{array}{c}\text { Hired } \\
(1000 \mathrm{VND})\end{array}$ & & & \\
\hline \multirow{4}{*}{$\begin{array}{l}\text { Ninh } \\
\text { hiep }\end{array}$} & High & 175.0 & 373.0 & 95.4 & 153.5 & 35.2 & 52.4 & 301.3 & 190.0 \\
\hline & Medium & 180.0 & 383.7 & 99.1 & 158.4 & 22.7 & 56.2 & 313.7 & 205.7 \\
\hline & Low & 171.0 & 350.6 & 89.8 & 151.2 & 0.0 & 55.7 & 296.7 & 205.1 \\
\hline & Average & 176.0 & 371.7 & 95.5 & 154.9 & 21.4 & 54.7 & 305.1 & 200.0 \\
\hline \multirow{4}{*}{$\begin{array}{c}\text { Dai } \\
\text { dong }\end{array}$} & High & 198.5 & 423.1 & 97.8 & 147.2 & 17.6 & 54.4 & 299.4 & 253.3 \\
\hline & Medium & 181.2 & 386.2 & 86.9 & 152.0 & 11.9 & 52.3 & 291.2 & 235.1 \\
\hline & Low & 168.0 & 344.4 & 83.1 & 152.0 & 0.0 & 52.3 & 287.4 & 209.0 \\
\hline & Average & 180.9 & 380.8 & 88.3 & 150.8 & 9.2 & 52.8 & 291.9 & 230.5 \\
\hline \multirow{4}{*}{$\begin{array}{l}\text { Tay } \\
\text { giang }\end{array}$} & High & 205.0 & 437.0 & 116.5 & 150.4 & 19.2 & 57.6 & 324.5 & 243.7 \\
\hline & Medium & 185.4 & 395.2 & 105.6 & 153.6 & 6.2 & 56.2 & 315.4 & 227.2 \\
\hline & Low & 168.0 & 344.4 & 96.4 & 145.6 & 0.0 & 56.7 & 298.7 & 191.3 \\
\hline & Average & 186.1 & 392.5 & 106.1 & 150.2 & 8.2 & 56.8 & 313.1 & 221.4 \\
\hline
\end{tabular}

Source: From field survey, February 2000

Table 7. Gross return and income from other crop in farm households (unit: 1000VND per sao)

\begin{tabular}{|c|c|c|c|c|c|c|c|c|c|c|c|}
\hline \multirow{2}{*}{$\begin{array}{l}\text { Com- } \\
\text { mune }\end{array}$} & \multirow{2}{*}{$\begin{array}{l}\text { Farm } \\
\text { group }\end{array}$} & \multicolumn{2}{|c|}{ Maize } & \multicolumn{2}{|c|}{ Peanut } & \multicolumn{2}{|c|}{ Sweet potato } & \multicolumn{2}{|c|}{ Soybean } & \multicolumn{2}{|c|}{ Vegetable } \\
\hline & & $\begin{array}{l}\text { Gross } \\
\text { return }\end{array}$ & Income & $\begin{array}{l}\text { Gross } \\
\text { return }\end{array}$ & Income & $\begin{array}{l}\text { Gross } \\
\text { return }\end{array}$ & Income & $\begin{array}{l}\text { Gross } \\
\text { return }\end{array}$ & Income & $\begin{array}{l}\text { Gross } \\
\text { return }\end{array}$ & Income \\
\hline \multirow{4}{*}{$\begin{array}{l}\text { Ninh } \\
\text { hiep }\end{array}$} & High & - & - & - & - & - & - & - & - & - & - \\
\hline & Medium & - & - & - & - & - & - & - & - & 348.2 & 204.7 \\
\hline & Low & - & - & - & - & - & - & - & - & 297.4 & 166.9 \\
\hline & Average & - & $\ldots$ & - & - & - & - & - & - & 213.6 & 123.6 \\
\hline \multirow{4}{*}{$\begin{array}{c}\text { Dai } \\
\text { dong }\end{array}$} & High & 251.4 & 98.2 & - & - & - & - & 305.6 & 171.9 & 320.5 & 190.4 \\
\hline & Medium & 223.4 & 87.2 & - & -- & - & - & 270.0 & 154.7 & 291.3 & 170.1 \\
\hline & Low & 204.8 & 85.1 & - & - & 129.0 & 69.6 & 243.0 & 151.3 & 273.4 & 156.3 \\
\hline & Average & 223.9 & 89.2 & - & - & 154.6 & 88.4 & 269.5 & 157.8 & 292.3 & 170.3 \\
\hline \multirow{4}{*}{$\begin{array}{l}\text { Tay } \\
\text { giang }\end{array}$} & High & - & - & 373.1 & 245.3 & 178.0 & 91.3 & - & - & 337.5 & 197.1 \\
\hline & Medium & - & - & 320.6 & 210.7 & 160.0 & 85.6 & - & - & 294.4 & 166.0 \\
\hline & Low & - & - & 262.5 & 170.3 & 135.2 & 69.9 & - & - & 270.3 & 159.5 \\
\hline & Average & - & - & 318.9 & 209.0 & 158.0 & 82.6 & - & - & 300.1 & 173.4 \\
\hline
\end{tabular}

Source: From field survey, February 2000

income because of their vague consideration on rice and the big hired labor cost.

(2) Winter crop production

In addition to rice, several secondary food crops including maize, soybean, potato, sweet potato, vegetables were planted in the winter crop after harvesting spring and autumn rice crops. These crops contributed significant shares to total crop income of farm households, especially for households in Daidong and Taygiang communes.

Due to better credit and assets equipment, high-income group in Daidong and 
Table 8. Total income from crop production in the farm household

\begin{tabular}{|c|c|c|c|c|c|c|c|}
\hline \multirow{2}{*}{$\begin{array}{l}\text { Com- } \\
\text { mune }\end{array}$} & \multirow{2}{*}{$\begin{array}{l}\text { Farm } \\
\text { group }\end{array}$} & \multicolumn{2}{|c|}{ Rice } & \multicolumn{2}{|c|}{ Other crops } & \multicolumn{2}{|c|}{ Total } \\
\hline & & $\begin{array}{c}\text { Sown area } \\
\left(\mathrm{m}^{2}\right)\end{array}$ & $\begin{array}{c}\text { Income } \\
(1000 \mathrm{VND})\end{array}$ & $\begin{array}{c}\text { Sown area } \\
\left(\mathrm{m}^{2}\right)\end{array}$ & $\begin{array}{c}\text { Income } \\
\text { (1000VND) }\end{array}$ & $\begin{array}{l}\text { Sown area } \\
\left(\mathrm{m}^{2}\right)\end{array}$ & $\begin{array}{c}\text { Income } \\
(1000 \mathrm{VND})\end{array}$ \\
\hline \multirow{4}{*}{$\begin{array}{l}\text { Ninh } \\
\text { hiep }\end{array}$} & High & 2760.0 & 1456.9 & 0.0 & 0.0 & 2760.0 & 1456.9 \\
\hline & Medium & 3667.0 & 1923.4 & 214.2 & 121.8 & 3881.2 & 2045.2 \\
\hline & Low & 3194.0 & 1754.8 & 303.7 & 140.8 & 3497.7 & 1895.6 \\
\hline & Average & 3231.3 & 1718.0 & 161.6 & 83.9 & 3392.9 & 1801.9 \\
\hline \multirow{4}{*}{$\begin{array}{c}\text { Dai } \\
\text { dong }\end{array}$} & High & 4438.0 & 3020.3 & 1376.0 & 494.5 & 5814.0 & 3514.7 \\
\hline & Medium & 4445.0 & 2776.3 & 1189.0 & 396.1 & 5634.0 & 3172.4 \\
\hline & Low & 4372.0 & 2498.9 & 1016.6 & 315.6 & 5388.6 & 2814.4 \\
\hline & Average & 4417.7 & 2740.2 & 1175.4 & 392.5 & 5593.1 & 3132.7 \\
\hline \multirow{4}{*}{$\begin{array}{l}\text { Tay } \\
\text { giang }\end{array}$} & High & 6363.0 & 4063.0 & 697.5 & 328.9 & 7060.5 & 4391.9 \\
\hline & Medium & 5425.0 & 3211.3 & 593.3 & 240.5 & 6018.3 & 3451.9 \\
\hline & Low & 5109.0 & 2662.0 & 401.8 & 145.1 & 5510.8 & 2807.0 \\
\hline & Average & 5611.6 & 3232.0 & 567.1 & 238.4 & 6178.7 & 3461.2 \\
\hline
\end{tabular}

Source: From field survey, February 2000

Taygiang applied most of inputs at higher level, and received higher gross return as well as income per unit of land as illustrated in table 7. Households in Ninhhiep engaged in winter crop cultivation at very small areas due to the low comparative advantage of winter crops compared to that of non-farming activities.

(3) Total income from crop production in the farm household

The total income from crop production in households came out from the rice and the winter crop production. The higher yield and income from all crops cultivation and the larger sown areas in high-income group in Daidong and Taygiang resulted in highest crop income of 3.5 and 4.3 million VND, respectively. These figures in medium and low-income groups were lower as showed in table 8 . In Ninhhiep commune, high-income households received the smallest income from crop production while the medium ones got the highest.

Over all, income from rice accounted for the main proportion of total crop income (around 95\%). This reflected the dominance of rice in the delta and the need for more diversified crop system in the region.

\section{Livestock production}

Pattern and herd size of major species raised

Dominant species raised in the locations under study were pig, buffalo, cattle and poultry. Pig rearing had been practiced since long and was closely linked with crop cultivation, primarily, rice farming. There were more than 80 percents of all farmers engaged in fattening pig. Sows were reared to produce piglets for domestic demand. Buffalo and cattle were raised for land preparation and were also regarded as long-term savings and security for farmers in the event of crop failure.

As illustrated in table 9 , there were larger variations in herd size among three locations and groups of farms. Livestock rearing in Daidong and Taygiang had been better developed. In these communes, the number of fattening pigs reared in 
Table 9. Average number of animal rearing in farm households (unit: head)

\begin{tabular}{cccccc}
\hline Commune & Farm Group & Fattening Pig & Sow & Buffalo and cattle & Poultry \\
\hline \multirow{4}{*}{ Ninhhiep } & High & 2.9 & 0.0 & 0.0 & 15.2 \\
& Medium & 3.1 & 0.1 & 0.1 & 16.2 \\
& Low & 2.8 & 0.2 & 0.0 & 10.4 \\
& Average & 2.9 & 0.1 & 0.1 & 14.4 \\
\hline \multirow{4}{*}{ Daidong } & High & 6.8 & 0.6 & 0.2 & 53.8 \\
& Medium & 4.1 & 0.5 & 0.3 & 25.3 \\
& Low & 2.4 & 0.1 & 0.0 & 12.6 \\
& Average & 4.2 & 0.4 & 0.2 & 28.0 \\
\hline \multirow{4}{*}{ Taygiang } & High & 7.8 & 0.5 & 0.2 & 56.4 \\
& Medium & 5.3 & 0.4 & 0.3 & 20.5 \\
& Low & 2.8 & 0.2 & 0.0 & 9.5 \\
& Average & 5.3 & 0.4 & 0.2 & 28.0 \\
\hline
\end{tabular}

Source: From field survey, February 2000

high-income groups was around 7 heads, in medium one was around 5 while this figure was around 2.5 in the low-income one. Lack of cash to purchase breeds and feed was the main reason for the small number of pigs to be raised in low-income groups. This was also the cause of low crop yield in their farm. Buffalo and cattle rearing only appeared in high and medium-income groups. The low-income one did not have these animal rearing because they could not afford to purchase the breeds, also. In Ninhhiep commune, the scope of livestock breeding was smaller compared to two above--mentioned communes, and medium income households ran this sector at the larger scope in comparison with high and low-income ones.

\section{Livestock Income}

(1) Income from fattening pig

Fattening pig rearing has been regarded as a major farming activity, and has been practiced by the majority of farmers in all locations. Furthermore, income from this enterprise always takes the primary proportion of total livestock income in almost farm households. Therefore, a profound analysis is necessary to understand this enterprise performance among farm household groups.

As the interview results, an average household reared between 3 and 5 pigs per year and the marketable size in kilograms per pig ranged from 60 to 100 . In Daidong and Taygiang, high-income households bought breeds at higher price for better quality. In addition, they invested more feed and vegetable for pig rearing as showed in table 10 . Consequently, these households were superior to others in marketable size of pig and obtained higher income. The medium and low income ones invested inputs at lower levels in both terms of quality and quantity. This resulted in their smaller marketable size of pig and lower obtained incomes. In Ninhhiep, fattening pig was also not paid much attention therefore the live weigh as well as income was smaller than those in Daidong and Taygiang.

Aside from live weights, farmers utilized manure to make compost for crop cultivation. Average compost produced from animal manure per households ranged from 
1.5 to 5 tons. This was one of important factors contributing to higher crop productivity in Taygiang and Daidong commune.

(2) Income from other animal species raised in farm households

In addition to fattening pig, sow and poultry rearing were performed in many households for income generation through the use of agricultural residues and

Table 10. Total return, cost and income per one fattening pig rearing in farm household

\begin{tabular}{|c|c|c|c|c|c|c|c|c|c|}
\hline \multirow{2}{*}{$\begin{array}{l}\text { Com- } \\
\text { mune }\end{array}$} & \multirow{2}{*}{$\begin{array}{l}\text { Farm } \\
\text { Group }\end{array}$} & \multicolumn{2}{|c|}{ Return } & \multicolumn{5}{|c|}{ Cost } & \multirow[b]{2}{*}{$\begin{array}{l}\text { Income } \\
(1000 \mathrm{VND})\end{array}$} \\
\hline & & $\begin{array}{c}\text { Live } \\
\text { weight } \\
\text { (kg) }\end{array}$ & $\begin{array}{c}\text { Gross } \\
\text { return } \\
\text { (1000VND) }\end{array}$ & $\begin{array}{c}\text { Breed } \\
(1000 \mathrm{VND})\end{array}$ & $\begin{array}{l}\text { Feeding } \\
(1000 \mathrm{VND})\end{array}$ & $\begin{array}{l}\text { Vegetable } \\
(1000 \mathrm{VND})\end{array}$ & $\begin{array}{c}\text { Other } \\
\text { (1000VND) }\end{array}$ & $\begin{array}{l}\text { Total cost } \\
\text { (1000VND) }\end{array}$ & \\
\hline \multirow{4}{*}{$\begin{array}{l}\text { Ninh } \\
\text { hiep }\end{array}$} & High & 68.3 & 614.7 & 167.8 & 222.1 & 43.2 & 33.6 & 466.7 & 148.0 \\
\hline & Medium & 70.1 & 642.3 & 172.7 & 213.9 & 42.3 & 36.1 & 465.0 & 177.3 \\
\hline & Low & 65.3 & 587.7 & 145.4 & 201.7 & 40.4 & 36.7 & 424.2 & 163.5 \\
\hline & Average & 68.3 & 619.0 & 164.2 & 213.7 & 42.1 & 35.4 & 455.4 & 163.6 \\
\hline \multirow{4}{*}{$\begin{array}{c}\text { Dai } \\
\text { dong }\end{array}$} & High & 91.5 & 874.8 & 214.4 & 305.4 & 58.7 & 45.6 & 624.1 & 250.7 \\
\hline & Medium & 81.0 & 732.8 & 188.0 & 263.8 & 48.9 & 41.7 & 542.4 & 190.4 \\
\hline & Low & 69.4 & 593.6 & 143.9 & 219.8 & 42.9 & 38.9 & 445.5 & 148.1 \\
\hline & Average & 79.6 & 719.6 & 179.2 & 258.8 & 49.3 & 41.7 & 528.9 & 190.7 \\
\hline \multirow{4}{*}{$\begin{array}{l}\text { Tay } \\
\text { giang }\end{array}$} & High & 96.7 & 924.3 & 226.5 & 323.2 & 62.0 & 48.1 & 659.8 & 264.5 \\
\hline & Medium & 84.2 & 761.0 & 195.2 & 273.7 & 50.8 & 43.4 & 563.1 & 197.9 \\
\hline & Low & 70.8 & 605.0 & 146.8 & 224.1 & 43.8 & 39.7 & 454.4 & 150.6 \\
\hline & Average & 83.9 & 763.2 & 190.1 & 273.7 & 52.1 & 43.7 & 559.5 & 203.7 \\
\hline
\end{tabular}

Source: From field survey, February 2000

Table 11. Return, cost and income from other livestock raising in the farm household (unit: $1000 \mathrm{VND})$

\begin{tabular}{|c|c|c|c|c|c|c|c|}
\hline \multirow[t]{2}{*}{$\begin{array}{l}\text { Com- } \\
\text { mune }\end{array}$} & \multirow[t]{2}{*}{$\begin{array}{l}\text { Farm } \\
\text { group }\end{array}$} & \multicolumn{2}{|c|}{$\begin{array}{l}\text { Poultry rearing } \\
\text { (Per household) }\end{array}$} & \multicolumn{2}{|c|}{$\begin{array}{l}\text { Sow rearing } \\
\text { (per head) }\end{array}$} & \multicolumn{2}{|c|}{$\begin{array}{c}\text { Buffalo \& Cattle rearing } \\
\text { (per head) }\end{array}$} \\
\hline & & Gross return & Income & Gross return & Income & Gross return & Income \\
\hline \multirow{4}{*}{$\begin{array}{l}\text { Ninh } \\
\text { hiep }\end{array}$} & High & 373.9 & 146.8 & 0.0 & 0.0 & 0.0 & 0.0 \\
\hline & Medium & 396.9 & 203.3 & 2166.5 & 836.9 & 1533.2 & 1134.0 \\
\hline & Low & 266.8 & 122.2 & 1689.8 & 617.0 & 0.0 & 0.0 \\
\hline & Average & 356.3 & 163.2 & 1289.1 & 489.0 & 613.3 & 453.6 \\
\hline \multirow{4}{*}{$\begin{array}{c}\text { Dai } \\
\text { dong }\end{array}$} & High & 1840.0 & 713.9 & 2724.7 & 1071.7 & 1386.4 & 1009.1 \\
\hline & Medium & 665.4 & 274.3 & 2458.6 & 928.9 & 1308.1 & 967.6 \\
\hline & Low & 287.6 & 128.9 & 1917.7 & 684.8 & 0.0 & 0.0 \\
\hline & Average & 826.8 & 333.3 & 2335.8 & 879.2 & 869.8 & 639.3 \\
\hline \multirow{4}{*}{$\begin{array}{l}\text { Tay } \\
\text { giang }\end{array}$} & High & 2041.7 & 751.7 & 2670.7 & 1039.9 & 1505.6 & 1139.3 \\
\hline & Medium & 541.2 & 219.2 & 2410.0 & 901.3 & 1434.7 & 1061.2 \\
\hline & Low & 226.1 & 100.1 & 1879.7 & 671.2 & 0.0 & 0.0 \\
\hline & Average & 896.8 & 343.3 & 2329.1 & 873.9 & 1025.6 & 766.3 \\
\hline
\end{tabular}

Source: From field survey, February 2000 
by-product from food processing. Buffalo and cattle were kept for draft power and producing income by supplying land preparation services.

Due to availability of cash, high and medium groups in Taygiang and Daidong performed these enterprises at larger scope as illustrated in table 8. Furthermore, higher income households also seemed to invest more feeding and other costs for animal raising. The cost for poultry rearing as well as for one sow rearing in high-income groups was higher than that in medium and low income ones. That was the main reason, which resulted in the great return in high-income groups and generated more cash for them while the low-income one received both smaller return and income from these enterprises as seen in table 11. For Ninhiep commune, these enterprises were developed better in medium-income group in both term of scope and obtained income.

(3) Total income from livestock breeding in the households

As illustrated in table 12 , livestock sector could bring the notably income for households. However, livestock income varied significantly among locations and farm groups. In Taygiang and Daidong, high-income group received over 3 million VND, while medium one got nearly 2 million VND and low one obtained only 0.6 million VND. This difference was caused by variance of herd sizes as well as investment levels among locations and farm groups. The profound cause was the different capacity of available credit among farm groups. However, in Ninhiep commune livestock income was lower than one million VND in all farm groups and the lowest of livestock income fell into the high-income one because livestock was considered as small or unimpantant sector in the commune, especially for high-income households.

Overall, fattening pig enterprise was the largest source of livestock income, accounted for 54.3 percent of total livestock income. Followings were poultry, sow rearing, buffalo and cattle enterprise.

Table 12. Total income from livestock breeding in the households

\begin{tabular}{|c|c|c|c|c|c|c|c|c|c|c|}
\hline \multirow{2}{*}{$\begin{array}{l}\text { Com- } \\
\text { mune }\end{array}$} & \multirow{2}{*}{$\begin{array}{l}\text { Farm } \\
\text { Group }\end{array}$} & \multicolumn{2}{|c|}{ Fattening pig } & \multicolumn{2}{|c|}{ Sow rearing } & \multicolumn{2}{|c|}{ Poultry } & \multicolumn{2}{|c|}{ Buffalo \& cattle } & \multirow{2}{*}{$\frac{\text { Total }}{1000 \mathrm{VND}}$} \\
\hline & & $1000 \mathrm{VND}$ & $\%$ & $1000 \mathrm{VND}$ & $\%$ & $1000 \mathrm{VND}$ & $\%$ & $1000 \mathrm{VND}$ & $\%$ & \\
\hline \multirow{4}{*}{$\begin{array}{l}\text { Ninh } \\
\text { Hiep }\end{array}$} & High & 421.8 & 74.2 & 0.0 & 0.0 & 146.8 & 25.8 & 0.0 & 0.0 & 568.6 \\
\hline & Medium & 549.6 & 55.0 & 104.6 & 10.5 & 203.3 & 20.3 & 141.8 & 14.2 & 999.3 \\
\hline & Low & 457.8 & 65.1 & 123.4 & 17.5 & 122.2 & 17.4 & 0.0 & 0.0 & 703.4 \\
\hline & Average & 481.9 & 62.2 & 72.7 & 9.4 & 163.2 & 21.1 & 56.7 & 7.3 & 774.6 \\
\hline \multirow{4}{*}{$\begin{array}{c}\text { Dai } \\
\text { Dong }\end{array}$} & High & 1704.8 & 52.2 & 643.0 & 19.7 & 713.9 & 21.9 & 201.8 & 6.2 & 3263.5 \\
\hline & Medium & 780.6 & 44.3 & 464.4 & 26.4 & 274.3 & 15.6 & 241.9 & 13.7 & 1761.3 \\
\hline & Low & 355.4 & 61.1 & 97.8 & 16.8 & 128.9 & 22.1 & 0.0 & 0.0 & 582.2 \\
\hline & Average & 862.9 & 50.0 & 380.8 & 22.1 & 333.3 & 19.3 & 147.2 & 8.5 & 1724.2 \\
\hline \multirow{4}{*}{$\begin{array}{l}\text { Tay } \\
\text { Giang }\end{array}$} & High & 2063.1 & 58.5 & 519.9 & 14.8 & 751.7 & 21.3 & 189.9 & 5.4 & 3524.7 \\
\hline & Medium & 1048.9 & 56.0 & 338.0 & 18.1 & 219.2 & 11.7 & 265.3 & 14.2 & 1871.4 \\
\hline & Low & 426.2 & 66.8 & 111.9 & 17.5 & 100.1 & 15.7 & 0.0 & 0.0 & 638.2 \\
\hline & Average & 1166.3 & 58.4 & 324.7 & 16.3 & 343.3 & 17.2 & 163.1 & 8.2 & 1997.4 \\
\hline
\end{tabular}

Source: From field survey, February 2000 
Table 13. Non-farming activities in farm households

\begin{tabular}{|c|c|c|c|c|c|c|}
\hline \multirow{2}{*}{$\begin{array}{l}\text { Com- } \\
\text { mune }\end{array}$} & \multirow{2}{*}{$\begin{array}{l}\text { Farm } \\
\text { Group }\end{array}$} & \multirow{2}{*}{$\begin{array}{l}\text { Number of } \\
\text { person engaged in } \\
\text { non-farming } \\
\text { (person) }\end{array}$} & \multicolumn{4}{|c|}{ Proportion of farm household engaged in: } \\
\hline & & & $\begin{array}{l}\text { Cereal milling \& } \\
\text { food processing } \\
(\%)\end{array}$ & $\begin{array}{l}\text { Cottage } \\
\text { industry } \\
(\%)\end{array}$ & $\begin{array}{c}\text { Trading } \\
\text { (\%) }\end{array}$ & $\begin{array}{l}\text { Working as } \\
\text { hired laborer } \\
\text { (\%) }\end{array}$ \\
\hline & High & 2.61 & 0.00 & 71.43 & 57.14 & 0.00 \\
\hline Ninh & Medium & 2.20 & 0.00 & 75.00 & 50.00 & 12.50 \\
\hline \multirow[t]{3}{*}{ Hiep } & Low & 1.50 & 20.00 & 40.00 & 20.00 & 60.00 \\
\hline & Average & 2.17 & 5.00 & 65.00 & 45.00 & 20.00 \\
\hline & High & 1.84 & 40.00 & 20.00 & 40.00 & 20.00 \\
\hline Dai & Medium & 1.15 & 25.00 & 37.50 & 12.50 & 25.00 \\
\hline \multirow[t]{3}{*}{ Dong } & Low & 0.73 & 0.00 & 14.29 & 14.29 & 28.86 \\
\hline & Average & 1.18 & 20.00 & 25.00 & 20.00 & 25.01 \\
\hline & High & 1.76 & 16.67 & 33.33 & 33.33 & 16.67 \\
\hline Tay & Medium & 1.28 & 25.00 & 37.50 & 12.50 & 25.00 \\
\hline \multirow[t]{2}{*}{ Giang } & Low & 0.82 & 16.67 & 16.67 & 16.67 & 33.33 \\
\hline & Average & 1.29 & 20.00 & 30.00 & 20.00 & 25.00 \\
\hline
\end{tabular}

Source: From field survey, February 2000

\section{Non-farming activity}

Types of non-farming activities.

As mentioned in occupation of farm households, many farm households were involved in non-farming activities. These activities could be categorized into four groups: firstly, food processing (noodle making, wine making, tofu making, and cereal milling); secondly, cottage industries or rural industry (tailoring, carpentry, medicine plant processing. etc); thirdly, trading (trading, shop keeping and retailing); and fourthly, working as hired laborers. Overall, households in Ninhiep commune engaged in non-farming activities at the highest rate. The traditional handicarft and cottage industry there were well developed due to their good production experience and advantageous access to the consumed markets.

There were more farm households of high-income group involved in non-farming activities than other groups. Farm households of low income engaged these activities at the lowest rate. Moreover, $20 \%$ of low-income households was found supplementing their small farm earning by working as hired laborer since they could not avail of other non-farming opportunities. The large number of high income households engaged in non-farming activities affirmed the conclusion that diversification of the household economy through the simultaneous development of farming and non-farming activities was the appropriate way to alleviate their poverty and improve the quality of life.

\section{Income of non-farming activities}

Income accruing from non-farming enterprises had been a considerable proportion of the farm household income, especially for households in Ninhhiep commune and for high-income households in all locations. Overall, average earnings from these activities per households ranged from 1.2 million to 11.3 million VND. With the better production equipment and working capital, high-income household operated non-farming activity at 
Table 14. Income from non-farming activities in the households (unit: 1000VND)

\begin{tabular}{|c|c|c|c|c|c|c|c|c|c|c|}
\hline \multirow[t]{2}{*}{$\begin{array}{l}\text { Com- } \\
\text { mune }\end{array}$} & \multirow[t]{2}{*}{$\begin{array}{l}\text { Farm } \\
\text { Group }\end{array}$} & \multicolumn{2}{|c|}{$\begin{array}{l}\text { Cereal milling \& } \\
\text { food processing }\end{array}$} & \multicolumn{2}{|c|}{ Cottage Industry } & \multicolumn{2}{|c|}{$\begin{array}{c}\text { Shop keeping and } \\
\text { trading }\end{array}$} & \multirow{2}{*}{$\begin{array}{l}\text { Income from } \\
\text { working as } \\
\text { hired laborer }\end{array}$} & \multicolumn{2}{|c|}{ Total } \\
\hline & & $\begin{array}{l}\text { Gross } \\
\text { Return }\end{array}$ & Income & $\begin{array}{l}\text { Gross } \\
\text { Return }\end{array}$ & Income & $\begin{array}{l}\text { Gross } \\
\text { Return }\end{array}$ & Income & & $\begin{array}{l}\text { Gross } \\
\text { Return }\end{array}$ & Income \\
\hline & High & 0.0 & 0.0 & 13608.8 & 6391.0 & 12677.0 & 4911.9 & 0.0 & 26285.8 & 11302.9 \\
\hline Ninh & Medium & 0.0 & 0.0 & 7191.8 & 3743.0 & 4738.8 & 1969.1 & 491.0 & 12421.6 & 6203.1 \\
\hline \multirow[t]{2}{*}{ Hiep } & Low & 198.8 & 72.7 & 2663.9 & 1278.3 & 978.3 & 377.7 & 956.0 & 4797.0 & 2684.7 \\
\hline & Average & 49.7 & 18.2 & 8305.8 & 4053.6 & 6577.0 & 2601.2 & 435.4 & 15367.9 & 7108.4 \\
\hline \multirow{4}{*}{$\begin{array}{l}\text { Dai } \\
\text { Dong }\end{array}$} & High & 300.8 & 174.1 & 4089.9 & 1868.1 & 5252.3 & 1816.9 & 430.7 & 10073.7 & 4289.8 \\
\hline & Medium & 472.5 & 262.5 & 2758.9 & 1303.5 & 2106.1 & 807.8 & 487.3 & 5824.8 & 2861.1 \\
\hline & Low & 145.8 & 84.3 & 914.8 & 472.0 & 593.0 & 255.1 & 536.9 & 2190.5 & 1348.3 \\
\hline & Average & 315.2 & 178.0 & 2446.2 & 1153.6 & 2363.1 & 866.6 & 490.5 & 5615.0 & 2688.8 \\
\hline \multirow{4}{*}{$\begin{array}{l}\text { Tay } \\
\text { Giang }\end{array}$} & High & 275.7 & 172.1 & 5345.9 & 2415.3 & 2816.9 & 1034.5 & 341.0 & 8779.5 & 3962.9 \\
\hline & Medium & 303.8 & 168.8 & 2471.2 & 1176.8 & 1446.4 & 576.9 & 476.9 & 4698.3 & 2399.4 \\
\hline & Low & 185.5 & 112.8 & 984.8 & 539.9 & 269.6 & 129.1 & 492.4 & 1932.3 & 1274.2 \\
\hline & Average & 259.9 & 153.0 & 2887.7 & 1357.3 & 1504.5 & 579.8 & 440.8 & 5092.9 & 2530.9 \\
\hline
\end{tabular}

Source: From field survey, February 2000

lager production scale. The given their larger production volume, high-income households obtained higher return and income than medium and low-income ones.

Overall, income from rural industry accounted for the highest proportion in all groups. This implied the importance of this kind of non-farming activities, which needed to be paid more attention for development in the future. Trading was also seen as the important one, especially for the high-income group. Although the low-income households engaged in non-farming activities, the ratio of farmers worked as hired laborers was high. Otherwise, their production volume of food processing, cottage industry and trading was small due to poor equipment and shortage of credit. It resulted in the state that they received only 2.6 million VND (for Ninhhiep) and 1.3 million VND (for Taygiang and Daidong) from non-farming activities, of which over 30 percent was obtained from working as hired laborer.

\section{The relationship between production activities in the farm households}

The different incomes from crop production, livestock breeding and non-farming activities resulted in large income gap among household groups. The low-income households received the smallest income while the high-income ones gained the greatest from all the enterprises as showed in table 4. A question arises as how are the

Table 15. Correlation coefficients between incomes from production activities in the farm households

\begin{tabular}{lccc}
\hline \multicolumn{1}{c}{ Activities } & Ninhhiep & Daidong & Taygiang \\
\hline 1. Crop production and livestock & 0.734 & 0.794 & 0.790 \\
2. Crop production and non-farming activity & -0.262 & 0.516 & 0.579 \\
3. Livestock and non-farming activity & -0.256 & 0.442 & 0.426 \\
\hline
\end{tabular}

Source: From field survey, February 2000 
relationships between production activities, or how is the impacts of one sector to another one in the farm households. For understanding these relations, the correlation coefficients between the incomes from three enterprises were computed. The outcome in table 15 indicated that the relationship between incomes from crop production and livestock rearing in farm households was positive and close to 1 in all locations. It could be explained by the fact that crop and livestock always closely related each other, and they were considered as integral parts of the farming system enterprises in the farm households in the delta. Crop cultivation provided the feed and cash for livestock breeding development. Inversely, livestock development supplied manure as well as draft power for crop cultivation. The performance of livestock breeding greatly influenced the development of crop production, especially crop yield, and vice versa.

In Daidong and Taygiang, both of crop and livestock sectors had the positive relation with the non-farming activities. Therefore, the development of one enterprise in these communes would create the credit source for enlargement requirement or development of other sectors. It in turn stimulated all components in the productive system to develop. However, in Ninhhiep commune, coefficients of income from crop production and non-farming, and from livestock and non-farming were negative. It indicated that the development of non-farming activities in Ninhhiep would not stimulate farming activities in this commune to develop.

\section{CONCLUSION}

There were considerable differences in socioeconomic characteristics among three farm income groups. High-income households appeared to own more educational attainments, more assets and cash for running farming work as well as other non-farming activities while medium and low-income ones equipped them at lower levels. Moreover, high-income households engaged more non-farming activities and had higher savings as compared to other ones.

Differences in economic and social conditions resulted in different productive scopes as well as various levels of applied input in farming operation among location and farm groups. In the communes that concentrated on farming as Taygiang and Daidong, high-income farms applied inputs at higher levels in both terms of quality and quantity for crop production and livestock breeding. As the result, they received more income from farming as compared to medium and low-income groups. In locations that farmers concentrated on non-farming as Ninhhiep commune, farm households in general, high-income ones in particular, did not pay much attention on farming therefore they applied inputs at lower rate and received small return and income from farming activities.

Non-farming activities with the dominance of cottage industry contributed meaningful proportion to total income of all farm households, especially for households in Ninhhiep where non-farming was considered as the vital activity. Due to availability of credit and asset equipment, high-income farm operated non-farming activities at larger scopes and obtained higher efficiency than other ones. The non-farming income, therefore, largely varied among farm households. In Ninhhiep, high-income group received 11 million VND, in Daidong and Taygiang, they received as much as 4 million VND, while the medium and low-income attained only around these half and quarter, 
respectively.

The positive correlation coefficients between incomes from crop and livestock in all locations indicated the very close relation between crop cultivation and animal rearing. It means that the integrated development of these two enterprises was necessary. However, the relationships between crop production and non-farming activities as well as livestock and non-farming activities were different among the locations. The negative coefficients in the case of Ninhhiep where is near to the city indicated that farmers there tried to utilize their comparative advantages to develop non-farming activities and paid a little bit on farming development. The positive coefficients in Daidong and Taygiang where are far from the city indicated that the diversification of the household economy through the simultaneous development of farming and non-farming activities in these communes was the appropriate way to alleviate poverty and improve the life quality of farmers. For doing so, a policy should be designed that aims at supporting credit for poor farmers so that they could further develop their production activities. Otherwise, creation of more employment opportunity is the efficient measure for farm household income improvement, especially for poor farmers.

\section{REFERENCES}

Chung. D. K. 1994 Agricultural Policy Reform in Vietnam-Perspective and Implication for Rice Economy, Dissertation No. AE 94-3, AIT, Bangkok, Thailand.

Tinh, N. D, 1995 Cultivation System in the Red River Delta, Publishing of Agriculture, Vietnam

World Bank, 1998 Advancing Rural Development in Vietnam: A Vision and Strategy for Action 